\title{
Reighan Gillam
}

\section{Learning to Transgress: Law 10.639 and Teacher- Training Classrooms in São Paulo, Brazil}

\begin{abstract}
Signed in 2003, Law 10.639 makes teaching AfroBrazilian history and culture compulsory in primary school lessons. Training programs to educate teachers on this material have proliferated in the state of São Paulo and elsewhere in Brazil. This paper illuminates non-elite Brazilians' lived, personal engagements with ideas of racial inequality by way of these training programs. Participants in these classrooms did not express direct rejection or acceptance of these ideas but rather relied on personal experiences to negotiate their conceptions of racial identity and racial inequality that deviate from traditional ideas of racial democracy. As Brazil takes further steps to consider race when facilitating access to resources and confronting racial inequality directly, it is imperative that the everyday iterations of this shift are understood. [Brazil, race relations, Law 10.639, teacher training]
\end{abstract}

As part of a series of training sessions ${ }^{1}$ to instruct teachers on how to integrate Afro-Brazilian history and culture into their curricula, trainer Flávia Gomes $^{2}$ screened clips from the film Everyone's Heroes (Heróis de Todo Mundo). This movie features prominent Afro-Brazilians and explains their role in national history. Flávia told the teachers that they could show this movie in their classrooms, or they could integrate the information from the movie into their lessons. Five female educators and I sat at our desks and quietly watched the clips that briefly recounted the lives and accomplishments of figures like Auta da Souza, an Afro-Brazilian writer, and Milton Santos, an Afro-Brazilian geographer. After showing the video, Flávia said a few words: "Violence is to whiten Black heroes. This silences the place of Blackness in the classroom. Machado de Assis, Lima Barreto. There is no way to silence this. (Não da para silenciar)." One of the participants raised her hand; Flávia called on her. She was a principal at an elementary school and participating in these classes to oversee the curricular changes at her school. Before saying anything, she began to sob, taking the entire class by surprise. "I feel so troubled because I didn't know these people had been left out. I have heard of them but didn't know they were Black. I liked reading the poems of Auta da Souza, but I always pictured her as White. The lack of information that we have..." Her comments trailed off as she wiped her tears. This response occurred toward the end of class, leaving Flávia with little time to initiate a conversation. Instead, she concluded class by adding a few words about using this video to educate children about the people presented in the movie before dismissing everyone for the day.

This scene played out in a teacher-training program in its first year in Flor do Campo, Brazil, in the state of São Paulo. These teacher-training programs resulted from the passage of Law 10.639, which made Afro-Brazilian history and culture compulsory material for all Brazilian public primary schools. Since its passage, teachertraining programs have proliferated throughout the country to provide teachers with classroom material about Afro-Brazilian history and culture to satisfy the legal mandate of Law 10.639. The teacher-training classrooms in which I participated were dynamic spaces of conversation, interaction, and engagement where Brazilians, like the principal above, could encounter new ways of thinking about race $^{2}$ that run contrary to the common belief that racism cannot naturally exist in a mixed-race society. This article aims to examine changing understandings of race in Brazil, not as it transforms larger social and political structures, but as it is continuously reframed on the microsocial or everyday level. I argue that the critical practice of learning about and responding to subjugated knowledge and alternative experiences have the potential to transgress boundaries of belonging and recognition of racial difference in Brazil. 
This article takes as a point of departure the issue of the personal in an era of changing conceptions of Brazilian race relations. This shift involves not only the macro changes of law and policy but also the personal, lived, everyday interactions of particular people as well. It uses the personal anecdotes, stories, and conversations of Brazilians offered during teacher-training sessions to examine how social change is a personal matter and how it plays out within everyday interactions. The "personal" broadly references the lived experiences of human beings. In several instances, the personal becomes the prism through which people perceive or react to macro-structural events and changing environments. I suggest that many Brazilians offer more personal responses to the shift from racial democracy based on their local and particular experiences as a way to account for the changes they are confronting in classroom education. While I would not say that these conversations were always successful at producing a shared understanding of the ways in which inequality can be tracked along racial lines, these teacher-training classrooms became sites and spaces of struggle over the limits and meanings of racial democracy and racial recognition, informed by the participants' personal experiences of race that they frequently voiced.

\section{RACIAL DYNAMICS IN BRAZIL}

Within the last 10 years, Brazilian public universities have established affirmative action policies or quotas $^{3}$ to racially and economically diversify their student population, which has unleashed unprecedented debates around the idea of race $^{4}$ and racial identity in Brazil. Mala Htun has characterized affirmative action in Brazil as an "absolutist issue where people have firm opinions" (2004:72). Indeed, the field is largely divided into two camps: those opposed to affirmative action on the basis that it is being imported from the United States and will introduce bipolar ideas of racialization in a country that has seen itself as racially mixed (Fry et al. 2007; Kamel 2007), and those in favor of race-based initiatives to generate increased Afro-Brazilian representation in higher education and further Afro-Brazilians' access to upward mobility (Heringer 1999; Siss 2003). These debates play out in the public venues of scholarly books, newspaper articles, and television documentaries at the national and international level. While affirmative action has incited quite charged public conversations about Brazilian race relations and the nature of racial inequality, Law 10.639 and the voices of everyday people have received less attention.

Affirmative action, Law 10.639, and other policies that recognize race are indicative of a general shift in racial dynamics characterized by a move away from racial democracy and toward racial recognition. The national ideal of racial democracy in Brazil foregrounds the mixture of Indigenous, African, and Portuguese populations in the heritage and identity of all Brazilians (e.g., Freyre 1944). Many Brazilians commonly believe that racial categories are indistinguishable due to this history of racial mixture and that racism cannot exist without clearly defined racial identities. Scholars have detailed the various ways in which many Brazilians continue to interpret their social relationships and personal identities through the lens of racial mixture and how this narrative downplays or erases attention to racism and racial inequality (Twine 1998; Burdick 1998; Goldstein 1999; Sheriff 2000).

Although it is common for many Brazilians to disarticulate the links between race and inequality, research studies have documented the economic, material, spatial, political, and educational margins in which many Afro-Brazilians operate (Silva 1985; Andrews 1991; Lovell 1999; Mitchell and Wood 1999; Telles 2004). As scholars have found in Puerto Rico (Godreau et al. 2008) and Ecuador (Johnson 2007; 2009), schools in Latin America are sites that reproduce national narratives that privilege racial mixture while tacitly promoting Whiteness as a positive identity. In the area of education, scholars have found unequal representation of Afro-Brazilians in didactic material and children's literature used within many primary schools (Deiro 1979; Negrão 1987; Munanga 1999; Lopes 2002). These studies demonstrate how, in school textbooks, Afro-Brazilians are either invisible or represented in stereotypical and limited roles when they do appear. Yet despite academic and activist attention to racial inequality, many Brazilians continue to deny that racial inequality plays a significant role in structuring opportunities for social mobility and accessing resources like education. This continued denial animates their resistance to new policies, like affirmative action, that recognize and seek to remedy the racial exclusion that has plagued Brazilian life.

The issue of racial inequality began to receive more attention after Brazil's governmental shift from a military dictatorship to a democracy and with the election of President Fernando Henrique Cardoso. As a graduate student, President Cardoso 
studied racial inequality in Brazil, which informed his openness to initiating and supporting affirmative action policies during his administration. Brazil's participation in the 2001 World Conference Against Racism in Durban, South Africa, was a catalyzing force that propelled the shift from racial democracy to racial recognition as a governing principle (Htun 2004). UN Ambassador Gelson Fonseca Jr. explained that Brazil's participation in the Durban conference "strengthened the political will for policies to combat discrimination and led to the first experiences with affirmative action for Afro-descendents" (quoted in Htun 2004:83). Elected in 2003, President Lula da Silva continued the momentum for racial inclusion by supporting further reforms. Former President Lula oversaw the creation of Secretaria de Políticas de Promoção da Igualdade Racial (Secretariat for the Promotion of Racial Equality), signed Law 10.639, and made November 20 a federally designated holiday called the Day of Black Consciousness.

By pushing for and implementing these policies, Afro-Brazilian activists have tirelessly advocated for the recognition of racism within everyday life (Hanchard 1994; Perry 2004; Caldwell 2007; Paschel and Sawyer 2008; Da Costa 2014). Paschel and Sawyer note that when social scientists and activists were "Armed with growing demographic data, they began to push on issues of discrimination, inequality, and the history of the brutality and resistance to slavery" (2008:202). However, the fact that policies that recognize racial inequality are gaining traction within the public sphere does not mean that more common understandings of what constitutes racism and racial identities have been totally transformed. In short, ideas of racial democracy within the general populace do not disappear in light of these new initiatives; in fact, common beliefs in the absence of racism animate resistance to these new policies. Alexandre Emboaba Da Costa writes:

These government initiatives have not guaranteed implementation, nor has federal policy created willingness among education secretaries, school administrators, and teachers to spend the time and money to realize projects related to Law 10.639. Discussion and implementation has depended on the advocacy and initiative of NGOs, scholars, and activists. [2010:208]

Thus, activists must continue to pressure local municipalities for the implementation of federal laws and policies around racial inequality. Policies that target racial inequality and inclusion have been viewed as top-down initiatives from the federal government. The voices of people who have not been the primary advocates of these policies have been elusive in the scholarship on the initiation of racial recognition policies in Brazil. I seek to place these shifts in racial discourse on ethnographic ground by stressing the lived, everyday engagement of people encountering these changes. ${ }^{5}$

Academic studies have demonstrated the value of probing the personal and intimate dimensions of racial democracy and racial identity in Brazil and Latin America. Peter Wade has argued that in addition to operating as a national ideology, mestizaje/mestiçagem is also a "lived process that operates within the embodied person and within networks of family and kinship relationships" (2005:239). Patricia Pinho underscores Wade's point by recounting a family story to probe "the meanings of mestizo phenotypes." However, Pinho examines how racism can operate as part of intimate kinship relationships. Pinho states:

And following Gail Lewis, I am disclosing my family memories to scrutinize the ordinariness of racist practices. Our ways and visions of being in the world are structured through racialized and gendered discourses and practices that require a feminist approach of highlighting what is political in accounts of personal experience. Through this process, the private, ordinary, and apparently insignificant aspects of daily life can be understood as shared experience, worthy of being theorized. [Pinho 2009:55-56]

Pinho and Wade maintain the centrality of the personal within notions of racial mixture and racial belonging in many Latin American countries where mestizaje defines the national narrative. Wade draws our attention to the personal, lived experiences of mestizaje as an understudied area in comparison to understandings of mestizaje as an ideology. He contends that, "Even anthropologistsand I include myself here-have tended toward the literate or discursive expressions of ideology when analyzing mestizaje. It therefore tends to be assumed that mestizaje is a nation building ideology, rather than a lived experience" (2005:242). This article builds upon this work by examining how people have continued to live and think about these processes of mixture during the recent shift to stateendorsed discourses on racial recognition in Brazil. 
A central premise of this article is that ethnographic treatment of people personally grappling with the move away from racial democracy is not only empirically valuable but also important to furthering our understanding of this social change as well. If the personal is one of the sites through which people think through racial politics, then we can learn a great deal by considering the ways Brazilians comprehend the shifting terrain of race relations.

The title of this article references bell hooks's treatise on educational practices called Teaching to Transgress: Education as the Practice of Freedom (1994), in which she connects knowledge, education, and teaching to struggles for social justice. In the book, she finds the classroom to be a "radical space of possibility" and discusses "teaching that enables transgression - a movement against and beyond boundaries" (1994:12). hooks champions teaching practices that enable students to "know beyond the boundaries of what is acceptable" (1994:12). In Brazil, "acceptable" ways of understanding race relations continue to be attuned by racial democracy. Silencing articulations of racism and racial inequality is one of the myriad ways this boundary is socially enforced. Robin Sheriff defines this silence as "cultural censorship" in that "the avoidance of open discussions on racism is directed toward the containment of racialized oppression" (2000:121). In the same vein, Kia Lilly Caldwell links this pervasive silence about racism to what she outlines as "mestiço essentialism," a set of discourses that "privilege a hybrid racial essence and, by so doing, both obscure racism and foreclose discussions of racial difference" (2007:18). France Twine found that Afro-Brazilians rarely discussed racism with their children. She argues, "Their silence, although strategic for the purposes of retaining employment and sustaining harmonious relations with the White elite, ultimately sustains White domination. These experiences disempower Afro-Brazilian children and adolescents, who learn that their experiences with racism are a taboo subject for discussion with their parents and peers" (Twine 1998:152-153). The maintenance of racial democracy works through silencing, avoiding, and evading open discussions of racism and racial difference, making the work of talking about issues of racial inequality a potentially transgressive act.

In these teacher-training classrooms, participants were systematically exposed to a counterhegemonic narrative of racial recognition through activities, information, curricular material, and personal stories about the experiences and histories of Brazilians racialized as Black. The material presented in these classrooms made interventions at the level of curriculum and also in teachers' general understandings of race and race relations in Brazil. Trainers attempted to move participants beyond the hegemonic discourse of racial democracy by informing them about racial inequality and its manifestation in education and other aspects of social life. Trainers also shared material that teachers could incorporate into their classroom lessons that would give visibility to Afro-Brazilian history and culture. Teachers' engagement with the trainers and this discourse of explicit racial recognition incited spirited and dynamic debates within the program.

\section{THE TEACHER-TRAINING PROGRAM}

Before discussing the activities in the teachertraining classrooms, I will briefly outline the structure and setting of the teacher-training program. The teacher-training program in which I was involved took place in a city 100 miles north of São Paulo called Flor do Campo. The inauguration of the training program resulted from demonstrations by local Black activists who lobbied their municipality to ensure schools followed Law 10.639 by integrating Afro-Brazilian history and culture into their curricula. The municipality finally acquiesced to these demands and approved a teacher-training initiative entitled Ação Africa, or Action Africa.

Project for Racial Consciousness (Projecto para Consciencia Racial), or PRC, won the contract to organize the teacher-training programs in Flor do Campo. PRC is a business in the city of São Paulo that works in the area of diversity training and research about the Afro-Brazilian population and inequality. Flávia Gomes, an Afro-Brazilian woman, is one of three people who run this business and invited me to attend the training sessions she facilitated. In addition to running PRC and facilitating teacher-training programs throughout the state of São Paulo, Flávia has organized conferences on Afro-Brazilian popular culture, spoken at various organizations and gatherings on the topic of racial equality, and been invited to national and international conferences to present her research and talk about struggles for racial recognition in Brazil. Flávia has a $\mathrm{PhD}$ in Communications from the University of São Paulo. I was introduced to Flávia when I began research in São Paulo in 2005; since then, she has been a generous collaborator and resource during my time in Brazil. I accompanied Flávia to her training classes, where I sat among the teachers 
and followed the lessons as a participant in the classroom. I chatted with the teachers during breaks and before and after class. At Flávia's request, I also gave a lecture to the class and led one of the discussions.

Action Africa was set up to run for six weeks in Flor do Campo. Teachers had to attend two classes per week for a total of 12 classes to complete the entire training program. Upon completion of the program, teachers received credit to maintain their certification as educators in the municipality's schools. The program offered several different time slots for classes to accommodate the 77 teachers who participated and their hours of availability. We taught a total of 10 classes per week over a 4-day time period, with five classes on one lesson and five classes on another. On Wednesdays, we taught three classes from 9.00 to 11.30 a.m., 1.00 to 3.30 p.m., and 5.00 to 7.30 p.m. On Thursdays, we taught from 9.00 to 11.30 a.m. and from 5.00 to 7.30 p.m. We followed the Wednesday schedule on Fridays and the Thursday schedule on Saturdays. We taught the same lessons on Wednesdays and Thursdays, and Fridays and Saturdays, respectively. During breaks, we ate lunch and had an afternoon snack, and then saved dinner for after the last class. We saw the same teachers at least twice a week.

Teachers were given a workbook of about fifty pages filled with PowerPoint slides that contained content for the classes. There was also room for teachers to write in the workbooks. Flávia commonly supplemented these workbooks with academic research articles, newspaper stories, movies, and other popular media. Teachers received the content in class and did not have any homework or outside research to do. Flávia explained that the curriculum needed to require little from teachers beyond their presence and participation in the program since their primary responsibility was teaching their classes.

Lesson themes centered on the structural inequalities that stigmatize Blackness and impact Afro-Brazilian students' experiences as other or marginal. The lessons were constructed to illuminate the ways in which racism was manifested within the curriculum, teachers' actions, and the interactions of students. In doing so, they also pointed to larger social structures and patterns of speech that infer racial preference and indicate a general racism in everyday acts and language. In this way, racism does not remain a phenomenon uniquely manifested only within the confines of school, but rather gets reproduced in larger social and cultural patterns of racial discrimination. Teachers were also given materials, such as movies, maps of Africa, ideas and information for lessons, songs, and techniques, to incorporate information about Afro-Brazilian history and culture into the classroom.

Many teachers claimed that they had not taken classes on this subject matter and therefore were confronting this type of material in a systematic way for the first time. Flávia always began the first class with an introduction to Law 10.639 and its goals to promote anti-racism in the classroom. After these talks, she asked the teachers if they had ever encountered this type of material. Normally the teachers would shake their heads no. In one session, however, a teacher raised her hand and claimed, "My education was not anti-racist, but that doesn't mean it was racist either." Many Brazilians resent the implication that they are exhibiting racist behaviors, which sociologist Florestan Fernandes famously described as the prejudice against having prejudice (preconceito de ter preconceito) (1960:iv). Another teacher in a different session defended the schools by saying, "We don't see this [racism] with the children. In my school we have one dark skinned girl (pretinha). Her father is Black (negro) and her mother is White (branca). She gets along fine with the other students. We just don't see this in the school." The second teacher's attempt to defend the school relied on narratives of racial mixture and apparent cordial relations between students to support her claim. Teachers were not openly hostile to the information presented by Flávia, but they did express resistance to considering how their schools could promote racial exclusion rather than harmonious race relations. These responses are consistent with the ideals of racial democracy that seek to deny the veracity of racism within social lives and everyday settings. In the next section, I turn to ethnographic descriptions of the teacher-training classrooms to present the lessons and conversations that emerged in these spaces. I also seek to show how everyday Brazilians are grappling with the shift from racial democracy to racial recognition.

\section{EVERYDAY RACISM}

One of the lessons, entitled "Culture and Ethnocentrism," covered the topics of race relations in Brazil, Eurocentrism, and the stigmatization of Blackness. This class was meant to act as a foundational introduction for teachers to understand how racism operates and discuss some of the 
mechanisms that continue its existence. It was positioned early in the curriculum to make teachers aware of the conditions that necessitated the curricular intervention of Law 10.639. In other words, before teachers were introduced to teaching material, the trainers sought to impart to teachers the need for these policies and diverse materials in the classroom. The overall goal of the lesson was to show teachers that ethnocentrism in Brazil worked by privileging Brazilians of European decent and stigmatizing Blackness. This ethnocentrism is communicated through references and actions during daily life.

A slide in the teachers' workbook defined ethnocentrism as "privileging the universe of representations as a model and reducing the significance of other universes and cultures that are perceived as different." Flávia explained that European culture and representations are privileged in Brazil and that this situation constitutes ethnocentrism. She said, "The goal of Law 10.639 is not to erase Europeans and their culture but to include others." She then moved on to discuss the interpretation of Brazilian race relations as harmonious due to racial mixture. Flávia invoked the work of Gilberto Freyre and his well-known book The Masters and the Slaves, in which he argued that miscegenation between Portuguese slave owners and enslaved Africans produced the cordial race relations and mixed-race population that uniquely mark Brazilian society. Flávia then said that this racial mixture was achieved through rape: "Mestiçagem was done through rape. People say that the Portuguese fell in love with the Indians. The Portuguese fell in love with Blacks. But it was through violence and rape." This phrasing disrupted the romantic picture that Freyre constructed by acknowledging the power relations and inequality that underwrote these sexual relations. During this part of the lecture the teachers remained quiet and listened to the trainer speak.

Flávia then went on to define race and ethnicity, and bring them into conversation with ideas of stereotypes and prejudice, discrimination, and inequality. She invited teachers to think about common Brazilian expressions that reflected prejudice against groups of people, particularly Afro-Brazilians. One of the teachers voiced the phrase, "Black with a White soul" (negro de alma branca), and another said, "to turn Black is to turn bad" (tornar negro, tornar ruin). Flávia asked the participants to consider these expressions within the context of the class material and pointed out that these expressions were quotidian or everyday phrases that express a stigma against
Afro-Brazilians. "Racism works through this kind of speech," Flávia stated. This speech gives preference to or valorizes Whiteness.

Flávia then moved on to discuss inequality and race in Brazil. She brought in an article from the newspaper Folha de São Paulo with the headline "Mortality of Blacks is greater than Whites" from August 25, 2005. She asked the teachers to take a moment to read the article. The article explained that the main cause of death among Blacks was violence. Flávia said, "The reasons are not biological; they are social. Blacks have less money, they live in the periphery, and they don't have access to health plans. We have to ask why? Why aren't there public policies that address AfroBrazilians in the area of health?" This part of the lesson came toward the end of class, and discussion in one of the classes became very animated. One of the participants, a gym teacher, began the discussion by relating an experience she had in a clinic: "I was in the waiting room of a clinic and I saw that a darker skinned Black woman got treated worse than I did." But then, she seemed to veer off the original theme of the conversation: "I was watching the 8:00 p.m. soap opera, and the main actor is Black and has a baby with the actress who is White. I have a Black parent and a White parent and I am very brown. The baby on television is darker than me, and I think the baby should be lighter." This comment sparked a lively conversation on the subject of color. Another teacher chimed in, "My father is very dark (Africano bem brava) and my mother is brown (morena) and I am the color I am." Then a third teacher said, "Well, two people can have twins of different colors." Someone pointed to Juliana (a woman with slightly olive skin and straight dark hair) and shouted, "Well, look at Juliana. She clearly has a foot in the kitchen (pé na cozinha)," a term commonly used to imply Black ancestry within one's heritage. A Black teacher stood up and stated, "No! This is a political matter. Juliana is seen as White and I am seen as Black!" Finally, a Black female teacher got in the last word with a personal anecdote:

I consider myself Black (negra). I arrived at this, because I was the darkest in my family and people considered my sister and me the Blacks of the family. My mother is a Portuguese descendent and mixed with Indian and my father is Black and mixed with Indian as well. Being Black can also have something to do with hair. My sister's hair is straighter than 
mine, so she may not be considered Black. For my mother's family, I was considered Black and for my father's family, I was not considered Black. Suddenly, I arrived at a crisis and wanted to know who I was. This search is a journey for all Afro-descendents (Afro-descendentes).

This conversation surpassed the 5:30 p.m. ending time of the class. After the teacher's statement, the trainer ended the class quickly with a lesson she attributed to Steve Biko, a South African freedom fighter whom I had become accustomed to her referencing. She said, "Many Blacks may look at their histories politically. When you claim your Blackness (assumir a negritude), you have to say that you are not inferior." Then, everyone quickly packed their bags and exited the classroom for the customary cafezinho (coffee) and biscoito (cookies) with which we typically ended the sessions.

I stayed in the classroom and helped Flávia clean up. She said, "Sometimes the teachers act more like their students by veering from the topic of conversation. It can be so difficult to keep them focused." Flávia was referring to the discussion at the end of the class in which the teachers did not seem to consider the dilemma of Afro-Brazilian mortality and the lack of public assistance directed at Afro-Brazilians that Flávia laid out for them. Instead their comments seemed to replay some of the common expressions surrounding race in Brazil, such as the "foot in the kitchen" comment and the constant references to racial mixture and skin color. At the end of the lesson, no consensus was reached and it was unclear to Flávia and me whether the teachers had actually understood the theme of the lesson - that race and inequality are linked and that everyday racial discourses have racial implications by tacitly reproducing assumptions about black inferiority.

I joined the teachers outside having coffee and I struck up a conversation with two of them. In trying to rectify what I considered the misunderstanding of the class lessons, I explained to the two female teachers that racism was an institutional and structural aspect of social life. I tried to explain that racial inequality made up part of a system and was less about individuals. One of them immediately said, "I don't see racismexcept that my father didn't like Blacks and didn't allow me to play with the neighbors who were Black." The other teacher chimed in with the anecdote that when she worked in a bank, a Black person was promoted to a higher position and the bank managers did everything they could to get rid of him. Then everyone started to separate and pack up to go home for the day.

Flávia and I were particularly frustrated after this class. Although the teachers were quite animated, we remained unsure if they had learned about systematic racism. Flávia also thought the conversation had veered off topic too many times. When I revisited my notes taken during these training sessions, I noticed a pattern of participants offering their own personal narratives and experiences to engage with the material. Furthermore, their personal stories were sites through which teachers could debate the meaning of racial democracy in response to Flávia's challenge to the dominant racial narrative. Flávia challenged the valorization of miscegenation by reframing it as rape and proceeded to discuss the valorization of Whiteness in everyday speech. When one teacher pointed to another and claimed that she had a "foot in the kitchen," this gesture asserted the hegemony of racial mixture by pointing to the potential mixed-race background of those who appeared to be White. Yet other teachers would not allow that interpretation to stand alone, pointing out that one can be seen as White, despite one's background. Finally, one Afro-Brazilian teacher offered a narrative that articulated the real struggles of Black Brazilians to negotiate racial hierarchies within their families and develop a positive Black identity. Flávia's data called into question the durability of the racial democracy thesis, which may have prompted the teachers to consider how their own personal narratives recast racial democracy as a site of struggle.

\section{HAIR TODAY}

One of the classes centered on the theme of valuing Black hair, or cabelo crespo. Flávia invited an Afro-Brazilian hair stylist named Mariana who specializes in hair braiding to talk to participants about valuing different hair types and styles in school. Flávia told the teachers that by touching some children on the head but not others, they express preference for certain children. She also discussed how children of African descent can feel ashamed of their hair texture or receive taunts from classmates because of it. The aesthetic hierarchy that privileges Whiteness as the standard of beauty and devalues Blackness has been well documented by scholars (Simpson 1993; Burdick 1998; Caldwell 2007). Nilma Lina Gomes found that many Afro-Brazilian women associated school with negative experiences surrounding their hair. 
She concluded that school is not a place where "Black people and their aesthetic are viewed positively" (Gomes 2003). While this scholarship details the racialized standards of beauty that leave out Afro-Brazilian men and women, these findings are not common knowledge to many Brazilians. Thus, Flávia sought to inform teachers of this differential aesthetic value and how actions in school reinforce and exacerbate it. She also tried to teach participants about how to value Black hair by showing them the technique of braiding as a specialized beauty practice.

Mariana led the interactive part of the class. First, she asked for a volunteer to be the model for the hair braiding. In one of the classes no one volunteered, so Mariana volunteered me to be the model. I sat in a chair and all the students circled around as Mariana braided my hair. She talked through each step of the style as she slowly wove sections of my hair into two neat, parallel plaits. After Mariana's demonstration, participants broke up into pairs or small groups and practiced braiding each other's hair. Male teachers practiced on women's hair though they did not have their hair braided. The idea was for teachers to practice, even if they could not create a braid that resembled Mariana's work.

During one of the lessons that focused on issues of Black hair, one of the more vocal teachers, Lourdes, started to discuss her daughter's hair in the group in which I was participating. As I watched Lourdes practice braiding Fabiana's hair she told us that her daughter absolutely hated her hair. She explained, "I cannot convince my daughter that her hair is beautiful. It has really affected her self-esteem." At that point, her face became strained from the concern over her daughter's feelings toward her hair, and she looked like she was about to cry. About two weeks before this hair lesson, during the first week of classes, Lourdes adamantly denied that racial difference and racism existed in Brazil, using as proof her own marriage to a Black man. She claimed that her daughter was not Black or White but mixed. However, during this lesson on hair, she recounted her own mixed-race daughter's struggles with self-esteem due to her kinky hair. Lourdes did not articulate a connection between her daughter's hair issues and the lesson about how Black features can be aesthetically devalued, but she did make a personal connection to the lesson and the issues it raised through the experience of her daughter. In these two contradictory moments of denying racial inequality because of her spouse and recognizing her daughter's self-esteem issues in the context of a class on anti-Black aesthetic standards, Lourdes provided an example of how the personal can operate as a site to contest or support racial democracy.

\section{PEDAGOGICAL POSSIBILITIES}

As part of one of the classes, a preschool teacher who worked with children up to 5 years old came and demonstrated one of the exercises she used to value all of the children in her class. She noticed that when she asked them to draw pictures of themselves, some of the Black children would draw themselves with blonde hair (como loiras) and blue eyes. "I guess that's how they see themselves," she said. "Or how they want to be," Flávia added. This pattern of self-representation as White with some of the darker children concerned her, so she developed an activity to encourage the children to draw themselves with more fidelity to their actual skin tones and features.

She presented a doll-making activity. She brought in a variety of different colored fabrics for students to choose from to make a doll in their own likeness. Before they could choose the fabric, she would read a story to them about the various colors that make up Brazil. The story was printed on construction paper and she included pictures cut out from magazines. The children would sit around her in a circle on the floor and she would read the story to them and show them the pictures. Then, she would have the children look at themselves in the mirror and, while looking at their reflection, choose a color from the fabric available that most closely resembled their shade. The children would proceed to make the dolls and she would display them around the room for a couple of weeks, after which the children could take the dolls home. Following these actions, she found that students would create dolls that looked like them, which she thought would help to validate all the children's looks and improve their selfesteem.

I include this activity to demonstrate some of the concrete strategies offered to teachers for valorizing students' racial identities in the classroom. Her pedagogical method recognized the color of each individual student and offered a way to encourage students to represent themselves as they are. This teacher recognized the racial implications of Black students' desires to represent themselves as White dolls and devised a means to recognize an individual person's color. 


\section{CONCLUSION:}

\section{AMBIVALENT RECOGNITION}

The ethnographic vignettes presented here highlight the ambiguous reception of lessons on racial difference and racial inequality presented in the teacher-training sessions I attended. Contrary to the polarized viewpoints on affirmative action presented by its most vocal proponents and opponents, there were few definitive moments in which a participant declared his or her allegiance to recognizing racial difference and that racism operated in systematic ways. Rather, teachers engaged with the information in personal ways and interpreted the material through the lens of their own experiences or that of their own personal relationships. Classrooms were spaces of ambiguity-they were conversational and flowing. While racial recognition policies are making headway within official spaces of public life, discourses that rely upon racial mixture continue to endure within some Brazilians' conceptions of themselves and their social relations.

Attempts to move beyond racial democracy must somehow contend with peoples' personal investment in racial democracy as a feature of their individual identities and social relations. Recognizing racism may be a personal matter, as in the case of the teacher who left the class sobbing upon realizing that she was unaware of the Black racial identity of a Brazilian historical figure with whom she had been familiar. Although government initiatives and support are opening spaces to promote an agenda of racial inclusion, for many Brazilians recognizing racism is a learning process. This process comes with all the attendant feelings of uncertainty that result from being asked to transgress familiar discourses, ideas, and ways of (not) talking about race, and to embrace an open conversation about the legacy of slavery and the endurance of racial inequality that has been silenced for so long. Teachers are being asked to see race in new ways, and this requires learning and adjusting oneself to new and different ways of thinking and talking about race.

As I have maintained in this article, we must complicate our understanding of the contemporary shifts in Brazil's racial policies by taking into greater consideration the lived ways Brazilians negotiate these changes. The social changes invoked by recent racial policies are entangled in the personal lives and experiences of Brazilians. This entanglement indicates a potential site that trainers could take into account when shaping their lessons. As recent laws and policies on race generate discussion among many Brazilians about the role of race and racial identity in producing social inequality, it is imperative that we comprehend this shift beyond polarized narratives but as an ongoing process that implicates the personal as well as the political.

\section{Reighan Gillam Department of Afroamerican and African Studies, Department of Communication Studies, University of Michigan, Ann Arbor, MI, 48103; reighan@umich.edu}

\section{NOTES}

1. I would like to thank John Burdick and Gladys Mitchell-Walthour for their comments on earlier versions of this article. The anonymous reviewers at Transforming Anthropology offered valuable insights to improve the manuscript. The research for this article was made possible by funding from Cornell University, a Five College Dissertation Fellowship, and FLAS fellowships.

2. I have used pseudonyms for the names of people and places.

3 . For more information on affirmative action or quotas in Brazil, see Pagano (2006) and Martins et al. (2004).

4. I use race to indicate not a biologically fixed category but a socially constructed and shifting set of discourses that stratify society and produce social inequality (e.g., Omi and Winant 2014).

5. See Baran (2007), Schwartzman (2009), and Collins (2011) for additional ethnographic studies that address shifting notions of race in Brazil.

\section{REFERENCES CITED}

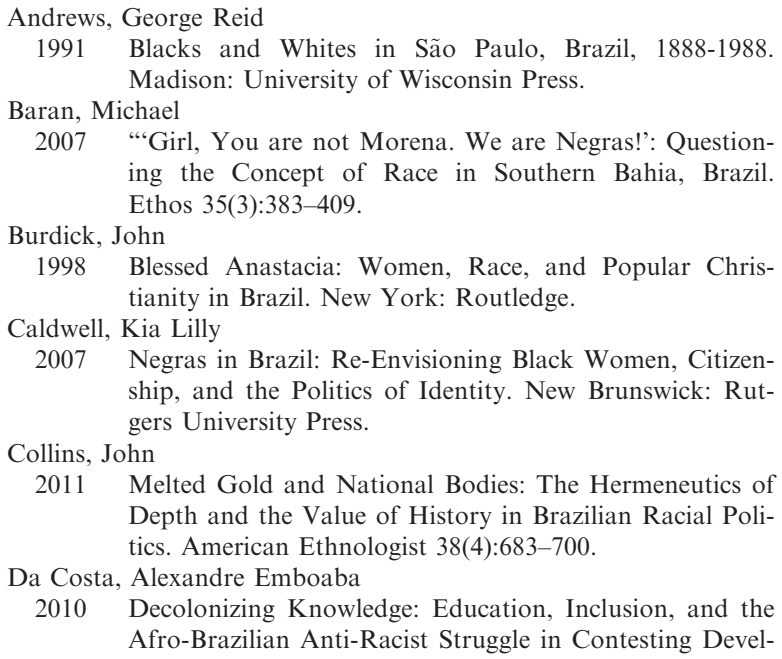

2007 Negras in Brazil: Re-Envisioning Black Women, Citizenship, and the Politics of Identity. New Brunswick: Rut-

2011 Melted Gold and National Bodies: The Hermeneutics of Depth and the Value of History in Brazilian Racial Politics. American Ethnologist 38(4):683-700.

Da Costa, Alexandre Emboaba

2010 Decolonizing Knowledge: Education, Inclusion, and the Afro-Brazilian Anti-Racist Struggle in Contesting Devel- 
opment: Critical Struggles for Justice and Social Change, Philip McMichael (ed.) Pp. 199-214. New York: Routledge.

2014 Reimagining Black Difference and Politics in Brazil: From Racial Democracy to Multiculturalism. New York: Palgrave Macmillan.

Deiro, Maria de Lourdes Chagas

1979 As Belas Mentiras: A Ideologia Subjacente Aos Textos Didáticos. São Paulo: Cortez/Moraes.

Freyre, Gilberto

1944 [1933] The Masters and the Slaves: A Study of Development of Brazilian Civilization. New York: Alfred E. Knopf.

Fry, Peter, Yvonne Maggie, Marcos Chor Maio, Simone Monteiro e Ricardo Ventura, eds.

2007 Divisões Perigosas: Politicas Raciais No Brasil Contemporaneo. Rio de Janeiro: Civilização Brasileira.

Godreau, Isar P., Mariolga Reyes Cruz, Mariluz Franco Ortiz, and Sherry Cuadrado

2008 The Lessons of Slavery: Discourses of Slavery, Mestizaje, Blanquemiento, in an Elementary School in Puerto Rico. American Ethnologist 35(1):115-135.

Goldstein, Donna

1999 "Interracial" Sex and Racial Democracy in Brazil: Twin Concepts? American Anthropologist 101(3):563-578.

Gomes, Nilma Limo

2003 Educação, Identidade Negra E Formação De Professores/As: Um Olhar Sobre O Corpo Negro E Cabelo Crespo. Educação e Pesquisa 29(1):167-182.

Hanchard, Michael

1994 Orpheus and Power: The Movimento Negro of Rio De Janeiro and São Paulo, Brazil, 1945-1988. Princeton: Princeton University Press.

Heringer, Rosana

1999 A Cor De Desigualdade: Desigualdade Raciais No Mercado De Trabalho E Ação Afirmativa No Brasil. Rio de Janeiro: IERE.

hooks, bell

1994 Teaching to Transgress: Education as the Practice of Freedom. New York: Routledge.

Htun, Mala

2004 From "Racial Democracy" to Affirmative Action: Changing State Policy on Race in Brazil. Latin American Research Review 39(1):62-98.

Johnson, Ethan

2007 Blackness, Identity, and Schooling in Esmeraldas, Ecuador. Race, Ethnicity, and Education 10(1):47-70.

Johnson, Ethan

2009 Schooling as a Regime of Equality and Reproducing Difference in an Afro-Ecuadorian Region. Ethnography of Education 4(1):147-164.

Kamel, Ali

2007 Não Somos Racistas: Uma Reação Aos Que Querem Nos Transformar Numa Nação Bicolor. Garulhos: Editora Nova Fronteira.

Lopes, Luiz Paulo da Moita

2002 Identidades Fragmentadas: A Construção Discursiva De Raça, Genero e Sexualidade Em Sala de Aula. Campinas: Mercado Aberto.

Lovell, Peggy

1999 Development and the Persistence of Racial Inequality in Brazil. Journal of Developing Areas 33(3):395-418.

Martins, Sergio da Silva, Carlos Alberto Medeiros, and Elisa Larkin Nascimento

2004 Paving Paradise: The Road from "Racial Democracy" to Affirmative Action in Brazil. Journal of Black Studies 34 (6):797-816.

Mitchell, Michael, and Charles H. Wood

1999 Ironies of Citizenship in Brazil: Skin Color, Police Brutality, and the Challenge to Democracy in Brazil. Social Forces 77(3):1001-1020.
Munanga, Kabengele

1999 Superando o Racismo na Escola. Brasília: MEC/Secretaria de Ensino Fundamental.

Negrão, Esmeralda V.

1987 A Discriminação Racial Em Livros Didáticos E InfantoJuvenis. Cadernos de Pesquisa 63.

Omi, Michael, and Howard Winant

2014 Racial Formation in the United States New York: Routledge.

Pagano, Anna

2006 The 'Americanization' of Racial Identity in Brazil: Recent Experiments With Affirmative Action in a 'Racial Democracy'. Journal of International Policy Solutions 6:9-25.

Paschel, Tianna, Mark Sawyer

2008 Contesting Politics as Usual: Black Social Movements, Globalization, and Race Policy in Latin America. SOULS Interdisciplinary Journal of Black Politics, Society, and Culture 10(3):197-214.

Perry, Keisha-Khan

2004 The Roots of Black Resistance: Race, Gender, and the Struggle for Urban Land Rights in Salvador, Bahia, Brazil. Social Identities 10(6):7-38.

Pinho, Patricia

2009 White but Not Quite: Tones and Overtones of Whiteness in Brazil. Small Axe: A Caribbean Journal of Criticism 13/2(29):39-56.

Schwartzman, Luisa Farah

2009 Seeing Like Citizens: Unofficial Understandings of Official Racial Categories in a Brazilian University. Journa of Latin American Studies 41:221-250.

Sheriff, Robin

2000 Exposing Silence as Cultural Censorship: A Brazilian Case. American Anthropologist 1:114-132.

Silva, Nelson do Valle

1985 Updating the Cost of Not Being White in Brazil. In Race, Class, and Power in Brazil. Pierre-Michel Fontaine, ed. Pp. 42-55. Los Angeles: Center for Afro-American Studies.

Simpson, Amelia

1993 Xuxa: The Mega-Marketing of Gender, Race, and Modernity. Philadelphia: Temple University Press.

Siss, Ahyas

2003 Afro-Brasileiros, Cotas E Ação Afirmativa: Razões Históricas. Rio de Janeiro: Quartet/PENESB-UFF.

Telles, Edward

2004 Race in Another America: The Significance of Skin Color in Brazil. Princeton: Princeton University Press.

Twine, France Winddance

1998 Racism in a Racial Democracy: The Maintanence of White Supremacy in Brazil. New Brunswick: Rutgers University Press

Wade, Peter

2005 Rethinking Mestizaje: Ideology and Lived Experience. Journal of Latin American Studies 37:239-257.

\section{Supporting Information}

Additional Supporting Information may be found in the online version of this article:

Figure S1. Doll made by children after an activity that valorized their own appearance. 